\title{
MODELLING LABOUR PRODUCTIVITY RATES FOR REINFORCEMENT WORKS
}

\section{A. KRAWCZYŃSKA-PIECHNA ${ }^{1}$}

\begin{abstract}
Summary: Construction planning always requires labour productivity estimation. Often, in the case of monolithic construction works, the available catalogues of productivity rates do not provide a reliable assessment. The paper deals with the problem of labour estimation for reinforcement works. An appropriate model of labour prediction problem is being introduced. It includes, between others, staff experience and reinforcement buildability. In the paper it is proposed, that labour requirements can be estimated with aggregated classifiers. The work is a continuation of earlier studies, in which the possibility of using classifier ensembles to predict productivity in monolithic works was investigated.
\end{abstract}

Keywords: reinforcement works, buildability, labour estimation, decision trees, classifier ensembles

\section{INTRODUCTION}

Monolithic works are one of the more expensive and more demanding construction works. They require a series of technologically dependent activities such as formwork erection and strike-off, placement of reinforcement steel, placement of concrete and an appropriate concrete curing. The largest single cost component of a concrete building's structural frame, which varies averagely between 35 and $45 \%$ of a reinforced concrete structure's unit cost [10,14], is formwork. This is why it was a subject matter of the previous Autor's research. However, formwork selection and formwork planning are not the only problems to solve. It has been observed for some time that there is a gradual decrease in the availability of highly qualified staff in Polish construction industry [18].

\footnotetext{
${ }^{1}$ PhD., Eng., Warsaw University of Technology, Faculty of Civil Engineering, Mechanics and Petrochemistry, ul. Łukasiewicza 17, 00-400 Płock, Poland, e-mail: Anna.Krawczynska@pw.edu.pl
} 
One of such professions is reinforcing ironworker. On the other hand, construction designs, including concrete ones, are becoming more and more complex and lean at once. This is why correct estimation of labour productivity gains in importance in construction planning. Problems observed during reinforcement works on different national construction sites over the past year were an inspiration to conduct an exploratory research on labour productivity of these works.

The paper deals with the problem of labour estimation for reinforcement works. An appropriate model of labour prediction problem is being introduced. It includes, between others, staff experience and reinforcement buildability. In the model it is proposed, that labour is being estimated with aggregated classifiers. The work is a continuation of earlier studies [10], in which the possibility and advantages of application of classifier ensembles to predict productivity in monolithic works was investigated.

\section{LABOUR ESTIMATION PROBLEM AND PROPOSAL OF ITS SOLUTION}

\subsection{LABOUR PRODUCTIVITY RATES}

The labour required to perform construction works is a key element in every construction estimation, in particular - in estimating cost and duration of works. It was a subject matter of various research, i.e. $[12,13]$. The most valuable source of knowledge about labour productivity is the estimator's own database, developed from the work his crews have handled in the past. When estimator's experience is poor or insufficient, labour estimation should be supplemented with manhour labour guides.

There are many man-hour reference data available. In Poland one can use KNR catalogues, issued in 80's and rarely updated since then. In the US available are Ed Sarviel's Construction Estimating Reference Data Tables [16] or DeWalt Construction Estimating Handbook [2]. In Germany and Austria labour can be estimated basing on Plümecke's guides [14], ARH Tabellen [1], guides by Meier, Dress \& Kurz, Hoffmann \& Kremer or Levsen [4, 5, 8]. Most of them are being updated every few years to make the estimation more reliable. Fig.1 below presents labour unit rates for wall and slab reinforcement works read from the sources mentioned above. As we can see, the differences between maximum, minimum and mean values are significant. 


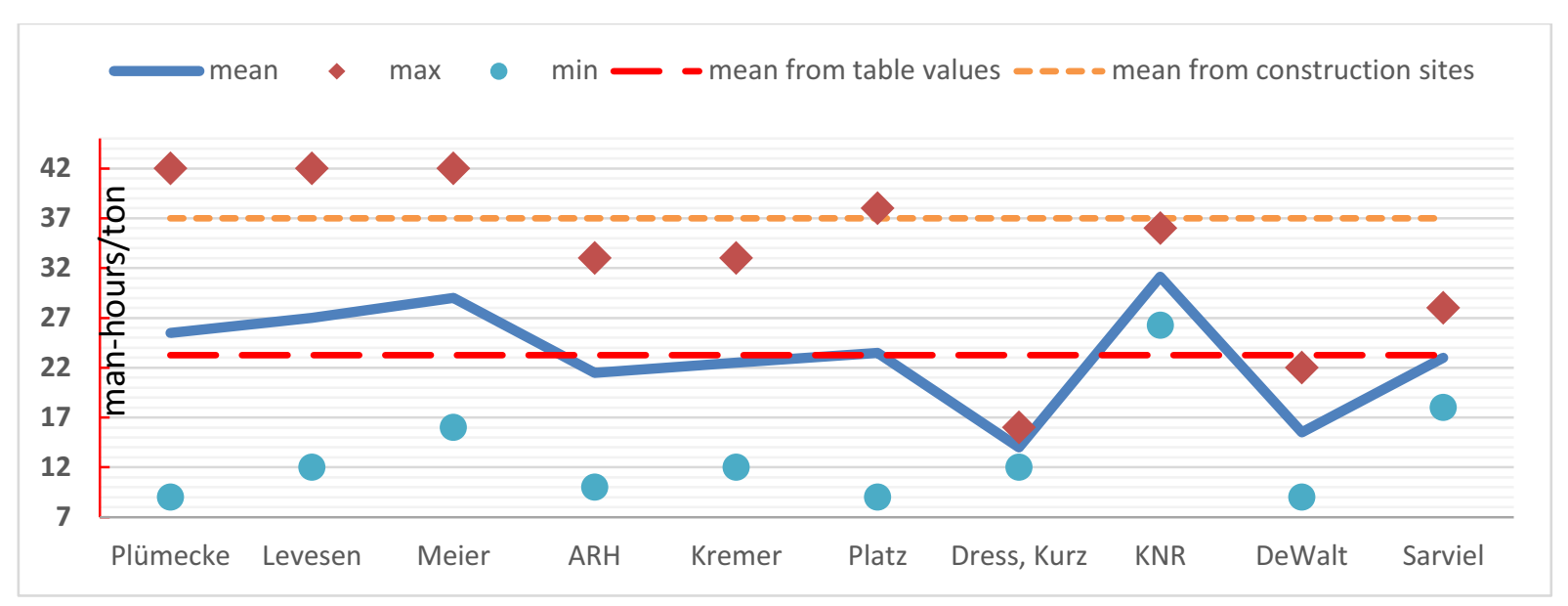

Fig. 1. Labour productivity unit rates for reinforcement works according to different guides and survey ran on investigated construction sites.

For all the values shown in Fig. 1. it is assumed, that placement of reinforcing steel includes handling into place, measuring, tying, supporting and cutting any necessary at the site such as cutting around imbedded items or cutting stock lengths of straight bars to fit slab dimensions. It also includes regular clean-up and infrequent correction and repairs required because of faulty installation. Polish KNR unit values include reinforcement preparation (cleaning, cutting and bending), which can be assessed as c.a. $25 \%$ of the total unit value and they were reduced in order to compare the data.

Regardless of the source and country, the man-hour tables are based on average man working under normal conditions: new construction with fair productivity, standard materials and straight-forward installation, appropriate tools, and good coordination with other trades. It is obvious that labour unit rates need to be adjusted due to specific job conditions, the questions are - to what extent? and what influences in the productivity most?

\subsection{MODELLING LABOUR PRODUCTIVITY FOR REINFORCEMENT WORKS}

\subsubsection{INITIAL SURVEY}

In order to establish parameters for the labour productivity model a brief survey among national construction supervisors and managers was conducted. On each of the investigated construction sites the reinforcement was partly pre-fabricated and required handling into place, tying, bending and cutting to fit structure's dimensions. No wire mesh nor pre-fabricated reinforcement baskets were used. The survey was intended to explore major problems faced by the planners and supervisors during reinforcement works. The questionnaire form was prepared basing on [9-11] and [15]. 
For 6 out of 11 investigated construction sites, the respondents claimed that the duration of reinforcement works, so also labour productivity, had been under-estimated in the planning phase. The respondents clearly indicted two main sources of disruptions in the performance of reinforcement works and made valuable remarks on problems occurring during works.

The first issue was ironworkers' skills and experience, or rather their lack. According to the respondents, low experience caused:

- problems with understanding design drawings ( 3 out of 11 construction sites),

- confusing reinforcement bar sizes, resulting from the above,

- confusing bar spacing, bar levels (upper and lower bottom) of two-ply reinforcement,

- problems with reinforcement proper position, stabilisation, tying and bending (4 out of 11 construction sites), see Fig. 2.
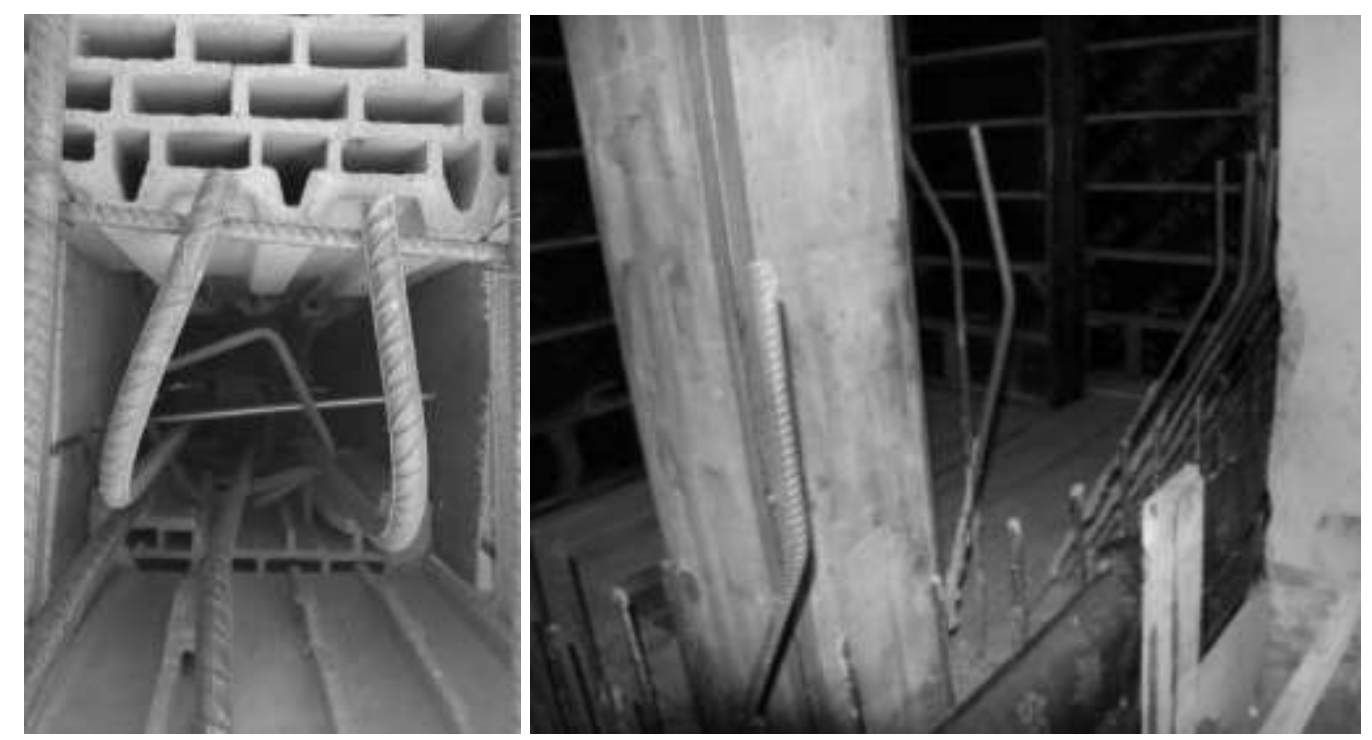

Fig. 2. The examples of poor experience of ironworkers: incorrectly tied reinforcement of a wall pillar (picture on the left) and a wrong position of starter bars (the bent ones) to be tied with reinforcement of a lift shaft (picture on the right).

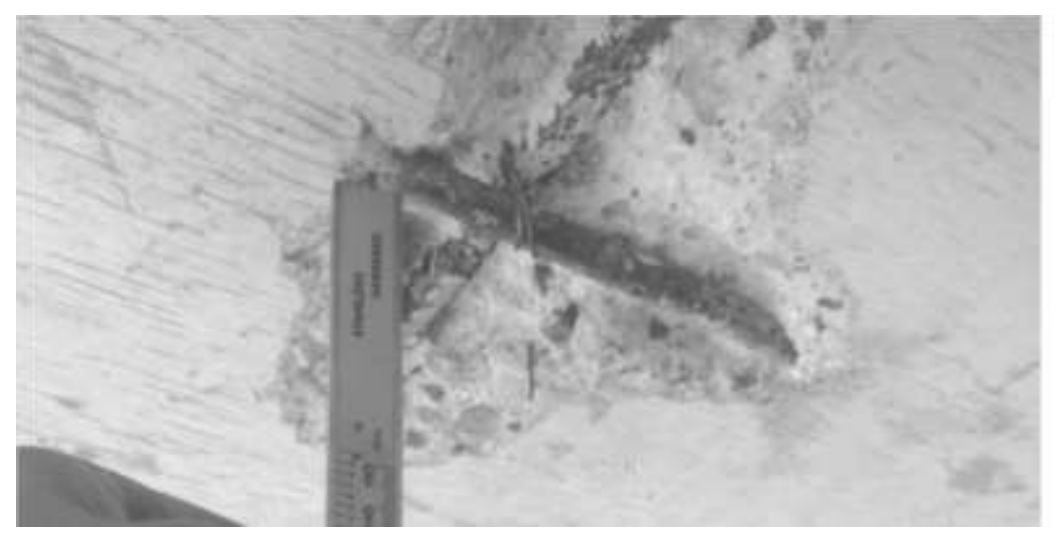

Fig. 3. Unacceptably low cover of slab reinforcement. 
- problems with providing proper cover for reinforcement bars in all types of construction (3 out of 11 construction sites), see Fig. 3.

The second problem issue reported by the construction supervisors ( 9 out of 11 surveys) was poor reinforcement and concrete structure buildability (or constructability). The term "buildability", according to [9] and [16] was defined as the ease and efficiency with which monolithic structure can be built. Among 11 investigated construction sites, the difficulties with reinforcement buildability included:

- over complex shapes of reinforcing bars and concrete elements (6 out of 11 construction sites): changes in the structure's cross-section causing bending of reinforcement bars, too many bar sizes in one element,

- insufficient tolerances to allow for other trades and over congestion (6 out of 11 construction sites), like in Fig.4, where the worker was not able to use his vibrating poker without touching the bars,

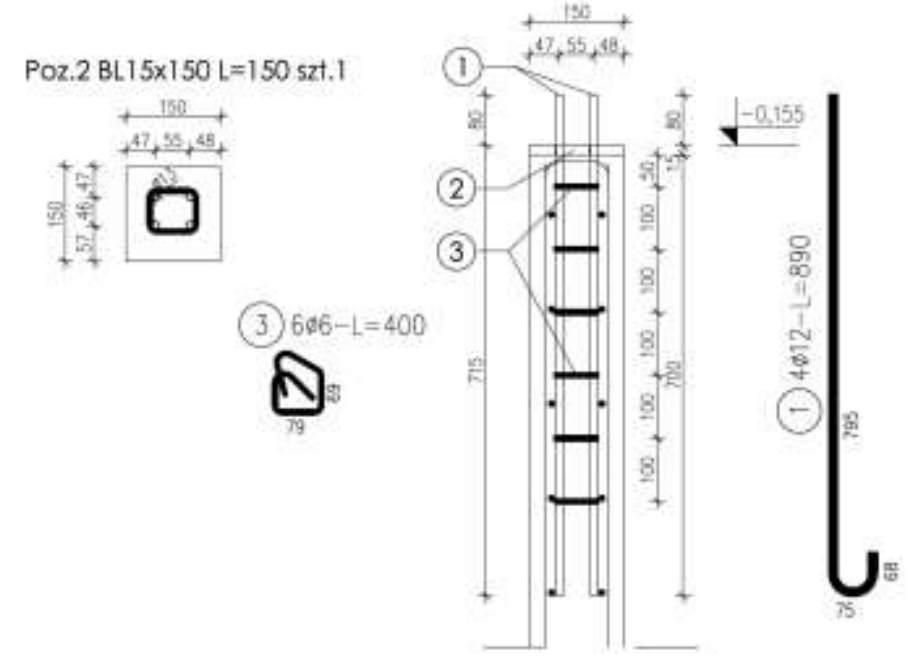

Fig. 4. An insufficient spacing of reinforcement bars - an excerpt from construction design.

- little consideration given to bending costs and cutting waste by designers (4 out of 11 construction sites),

- too many different reinforcement spacing in one element or cross-section (4 out of 11 construction sites),

- custom reinforcement spacing (3 out of 11 construction sites): half values, values which are not multiples of $5 \mathrm{~cm}$,

- not enough consideration given to the practicality of details, nor to the effect they may have on the construction as whole (4 out of 11 construction sites). 
Superficially ergonomic designs were often more costly in construction time due to their complex shapes or processes of construction. If we combine it with low employee skills - we have to expect a high probability of exceeding the assumed duration of reinforcing works. Improperly carried out works require a number of amendments (bars re-bending or re-tying, placing additional bars, etc.) which delays concrete placing or requires repairs to be done after formwork strike-off, like in Fig. 3 , which in turn delays the start of other works in this location.

\subsubsection{MATHEMATICAL MODEL PROPOSAL FOR LABOUR ESTIMATION PROBLEM}

In order to estimate labour required to perform reinforcement works, it is proposed to apply classification methods. Prediction algorithms were used i.e. by Drozd to model construction site accidents [3] or Gajzler et al. to choose the best decision supporting method [6]. In the following paper it is being proposed to use aggregated classifiers. The advantage of applying classifier ensembles was explained in [10] and consists in building different models of the same phenomenon and then combining their judgments. Classifier ensembles, especially those based on decision tress or random forests, according to [7] are thought to be the most effective classifiers, which do not require any initial data treatment, pre-processing and analysis.

Let's consider set $U$ containing $N$ observations which are different reinforcement tasks. Each observation is described by a vector of attributes $\left[x_{i 1}, x_{i 2}, \ldots, x_{i L}, y_{i}\right]$. There are two kinds of attributes: predictors (the input data) $X_{1}, \ldots, X_{L}$ and one target attribute $Y$ (the output data). Variables $x_{i 1}, x_{i 2}, \ldots, x_{i L}, y_{i}$ describe attributes' values for the observation $i(i=1,2, \ldots N)$. The value of the target attribute is a class label. Therefore, set $U$ can be defined as in Eq.(2.1):

$$
\left[x_{i}, y_{i}\right]_{N \times(L+1)}=\left[\begin{array}{cccc}
x_{11} & \ldots & x_{1 L} & y_{1} \\
x_{21} & \ldots & x_{2 L} & y_{2} \\
\ldots & \ldots & \ldots & \ldots \\
x_{N 1} & \ldots & x_{N L} & y_{N}
\end{array}\right]
$$

Predictors are different circumstances in which reinforcement is being placed into concrete construction. In the proposed model of prediction predictors are as follows: the type of reinforced construction element, work experience of ironworkers, the buildability of the reinforced element, necessity for additional reinforcement bending, necessity for additional reinforcement cutting and general placement conditions. The target attribute is the range of values of man-hours required to place the reinforcement. The goal of the classification problem is to construct, using the historical data, a mathematical model that predicts the class of the unlabelled examples. This means that the dependence between the labour productivity $Y$ and the circumstances of reinforcement works 
$X=\left[X_{1}, \ldots, X_{L}\right]$ is being sought. The predictors and a range of their possible values are collected in Table 1, while Table 2 presents possible values of the target attribute.

Table 1. Predictors and their values.

\begin{tabular}{|c|c|}
\hline $\begin{array}{c}\text { Predictor's description } \\
\text { Type of reinforced } \\
\text { construction element }\end{array}$ & Possible input values \\
\hline $\begin{array}{c}\text { Work experience of } \\
\text { ironworkers }\end{array}$ & slab (s), wall (w) \\
\hline Low (l) - less than 3 years \\
Average (a) - between 3 and 12 years (incl.) \\
High (h) - more than 12 years
\end{tabular}

Table 2. Target attribute and its values.

\begin{tabular}{|c|c|}
\hline Target attribute & Possible output values \\
\hline & $<30$ man-hours/ton \\
Labour productivity & $30-40$ man-hours/ton \\
& $40-50$ man-hours/ton \\
& $>50$ man-hours/ton \\
\hline
\end{tabular}

Target attribute values were established arbitrarily basing on the survey, where the average labour was at c.a. 37 man-hours/ton, and labour guides as in Fig.1. 


\subsubsection{ESTIMATING LABOUR PRODUCTIVITY RATES WITH DIFFERENT TYPES OF CLASSIFIERS}

To build prediction models the data collected on the investigated construction sites were used. The result of the survey was a collection of 29 observations, see Fig.5, related to reinforcement placing into horizontal structures (slabs or slabs and beams). The crews consisted of 1 to 3 workers and the crew's experience was calculated as an average work experience of ironworkers and helpers. The labour measured included initial cleaning, handling into place, tying, stabilisation, necessary cutting, bending and amendments, if required.

\begin{tabular}{|c|c|c|c|c|c|c|c|}
\hline \multicolumn{8}{|c|}{ Raiation Ezrajenia } \\
\hline Na & t takmant & 2. cosenance 3 & 7 buidioith & 4. condang & 5. cuthng 8 & 7. consions & 7 productiven \\
\hline 1 & 8120 & 1 & 30 & 0.8 & 0.0 & 00 & $40-50$ \\
\hline 2 & 3130 & i & 30 & 00 & 1.0 & 00 & $40-50$ \\
\hline 3 & s120 & $\mathrm{h}$ & 30 & 10 & 10 & 10 & ao \\
\hline 4 & siag & n & 10 & 10 & 20 & 00 & $30-40$ \\
\hline 5 & gisa & h & 20 & 10 & t.0 & 00 & $30-40$ \\
\hline 5 & alas & 1 & 30 & 10 & 10. & 10 & 30.40 \\
\hline 7 & gigb & 1 & 20 & 10 & 1.0 & 00 & 160 \\
\hline 8 & siac & -3 & 40 & 00 & 200 & 10 & $30-40$ \\
\hline$\Rightarrow$ & 3125 & a & 30 & 00 & 1.0 & 00 & $40-50$ \\
\hline 10 & slag & h & 10 & 20 & 20 & 00 & $30-40$ \\
\hline 11 & siat & $a$ & 20 & 10 & 10 & 00 & $40-50$ \\
\hline 12 & 9192 & a & 30 & 10 & 20 & 0.0 & $30-40$ \\
\hline 13 & slab & a & 30 & 20 & 20 & 00 & 30.40 \\
\hline 14 & siab & b & 40 & 00 & .0 .0 & 10 & $30-40$ \\
\hline 15 & 8130 & 1 & 40 & 00 & 1.0 & 0.0 & $40-50$ \\
\hline 10 & stao & a & 20 & 10 & 1.0 & 0.0 & $40-50$ \\
\hline 17 & stab & n & 40 & 10 & 20 & D. 0 & 30 \\
\hline 18 & sian & 3 & 30 & 10 & 0.0 & 00 & $30-40$ \\
\hline 19 & 8120 & n & 20 & 0.0 & 0.0 & 10 & $30-40$ \\
\hline 20 & slan & 1 & 30 & 10 & 10 & 00 & $40-50$ \\
\hline 21 & slas & a & 40 & 0.0 & 20 & Do & 40.50 \\
\hline 22 & 9130 & 1 & 30 & 0.0 & 1.0 & 10 & $40-50$ \\
\hline 23 & sist & $a$ & 20 & 10 & 1.0 & 10 & $40-50$ \\
\hline 24 & slah & h & 20 & 20 & 1.0 & 10 & $40-50$ \\
\hline 25 & siab & $a$ & 20 & 10 & 10 & 00 & $30-40$ \\
\hline 26 & 9196 & 1 & 20 & 10 & 1.0 & 00 & 60 \\
\hline 27 & atho & n & 40 & 10 & 1.0 & 10 & (30) \\
\hline 28 & s120 & a & 10 & 2.0 & 20 & 10 & 80 \\
\hline 20 & 8180 & 3 & 10 & 10 & 20 & 00 & 40.50 \\
\hline
\end{tabular}

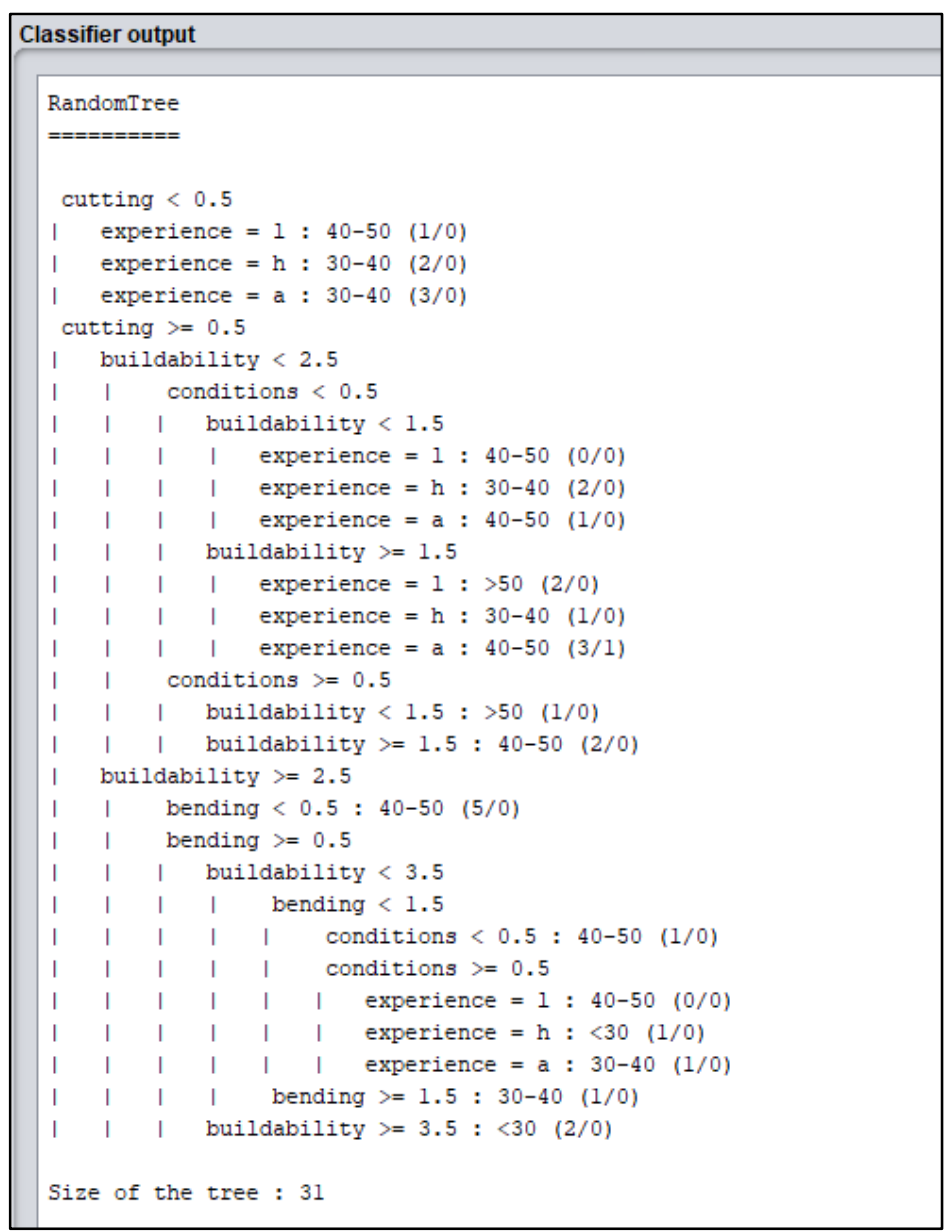

Fig. 5. The collected data (on the left) and the best-fitting Random Tree classifier (on the right)

Having such a set of data it was possible to build classifier that estimates labour productivity. In order to obtain training sets, cross-validation with different number of folds was performed (from 5 to leave-one-out cross-validation). The maximum number of iterations was set to 100 and no resampling was allowed. All the calculations were performed with Weka 3.8. software. 
In the first step single classifiers were sought. Fig. 5. presents one of such classifiers, a Random Tree, which accuracy was at $65,5 \%$. It was the best fitting single classifier from all the investigated trees (Random Tree, Decision Stump, LMT, J48). As the classification accuracy was not satisfactory, the base classifier was aggregated with different meta-algorithms. Boosting procedure with the AdaBoost.M1 algorithm improved the accuracy up to $73 \%$ and reduced the mean error down to 0,17 . The best fitting classifier turned out to be Random Forest with the accuracy at $79 \%$, see Fig. 6.

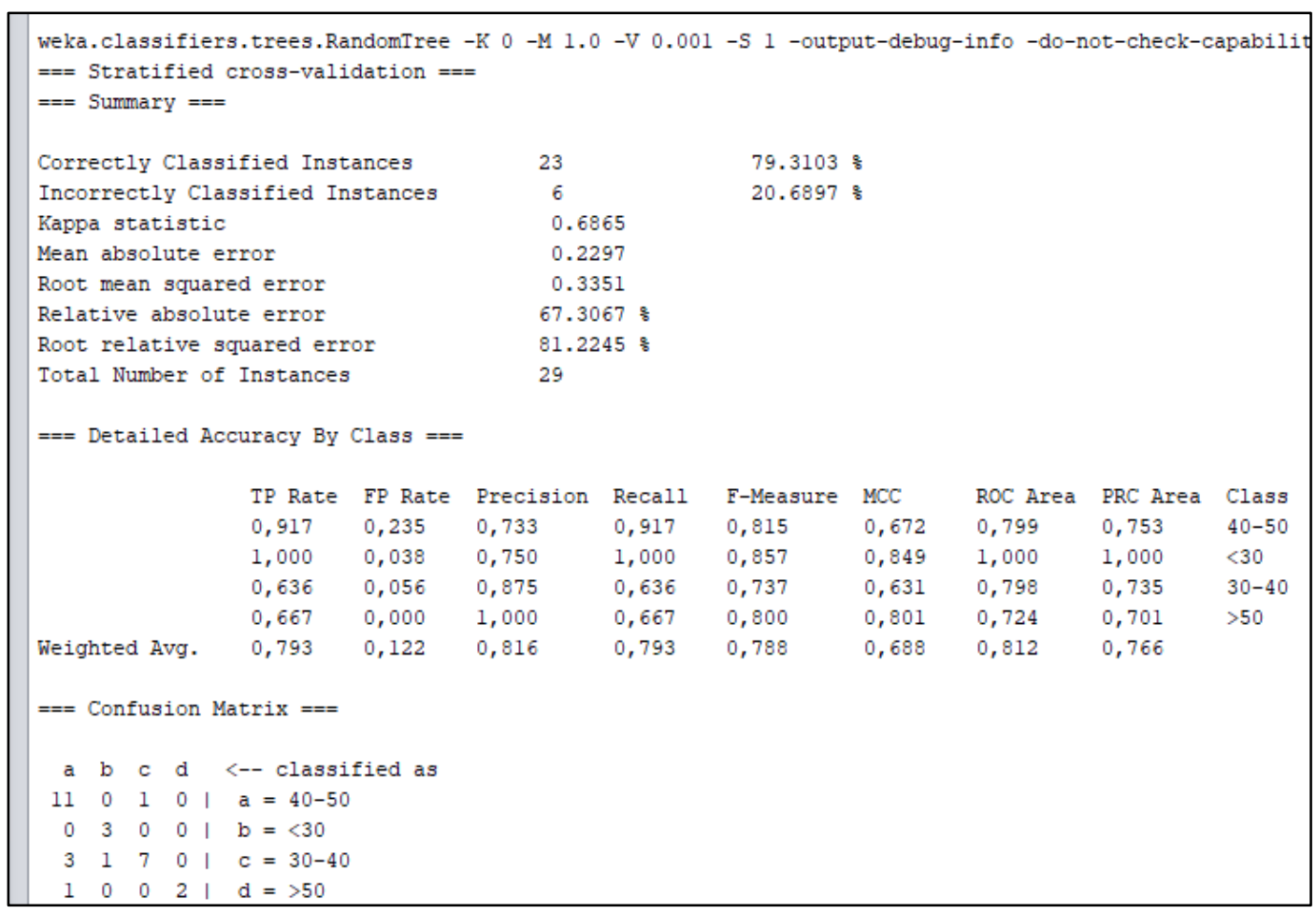

Fig. 6. Random Forest estimation accuracy measures.

The results of classification are promising, however, for fear of over-training and over-fitting at once it is necessary to complete the database with more data and learn the classifier again. It is also necessary to complete the database with observations regarding vertical (wall) reinforcement. 


\section{CONCLUSIONS}

Labour productivity is a key information for estimating and project planning. The current practice of labour productivity estimation relies primarily on either published productivity data or an individual's experience. As Song and AbouRizk notes in [12], there is no systematic approach to measuring and estimating labour productivity. The paper attempts to solve this problem. A simple concept model of labour estimation involving classifier ensembles (boosted decision trees) was proposed. Predictors, target attribute and their possible values were defined. Of course, it would be desirable if the ranges of output's values were narrower, which would be more useful in precise estimating the duration of works. Yet it requires further research and data collection. What deserves mention, an exploratory research indicated two main sources of disruptions in labour estimation for reinforcement works. These are: low crew experience and poor buildability of reinforcement and construction elements. This second issue requires special attention, as buildability seems to be under-valuated and undetermined among designers. There are no national standards for buildability assessment and there are still designs with a large number of construction details difficult to implement, although modern design techniques, including the BIM technology, allow to improve their buildability. The paper suggests a simple manner of reinforcement's buildability assessment.

\section{REFERENCES}

1. ARH Arbeitszeit-Richtwerte, “Teilausgabe Stahlbetonarbeiten”, Zeittechnik Verlag, Neu-Isenburg, 2015.

2. A. Ding, "DeWALT Construction Estimating Complete Handbook", Cengage Learning, 2016.

3. W. Drozd, M. Kowalik, "Decision trees algorithm in the analysis of the construction site accidents", Scientific Review - Engineering and Environmental Science, 26(2): 226-233, 2017.

4. C. Hofstadler, "Kalkulation von Stahlbetonarbeiten", Vorlesung, Technische Universität Graz, 2011.

5. C. Hofstadler, G. Franzl, "Bewehrungsarbeiten in Baubetrieb”, Verlag des VÖBV, 2011.

6. M. Gajzler, A. Dziadosz, P. Szymański, „The problems of choice of decision making support method in construction", Technical Transactions, 1-B (B): 71-84, 2010.

7. E. Gatnar, "Multi-model approach in discrimination and regression", PWN, Warsaw, 2009.

8. G. Grimscheid, C. Motzko, "Kalkulation, Preisbildung und Controlling in der Bauwirtschaft", Springer Verlag, 2013.

9. G. Jergeas, "Detailed Design and Constructability", PhD Thesis, Loughborough University of Technology, United Kingdom, 1989.

10. A. Krawczyńska-Piechna, "Modelling Labour Rates in Concrete Construction Planning", Acta Sci. Pol. Architectura 16(2): 13-19, 2017.

11. R. L. Peurifoy, G. D. Oberlender, "Formwork for Concrete Structures”, McGraw-Hill, New York, 2011.

12. E. Plebankiewicz, J. Malara, "The algorithm for the evaluation of construction workers' labour productivity", Technical Transactions 6: 153-161, 2017.

13. E. Plebankiewicz, M. Juszczyk, J. Malara, "Identification and evaluation of factors affecting the performance of construction workers", Scientific Review - Engineering and Environmental Science 23: 271-278, 2014.

14. K. Plümecke, V. Kühne, M. Kattenbusch, "Preisermittlung für Bauarbeiten”, Verlagsgesellschaft Rudolf Müller GmbH \& Co. KG, Köln, 2017. 
15. D. G. Proverbs, G. D. Holt, P. O. Olomolaiye, "Construction Resource/Method Factors Influencing Productivity for High Rise Concrete Construction”, Construction Management and Economics 17: 577-587, 1999.

16. E. Sarviel, "Construction Estimating Reference Data", Craftsman Book Company, Corte del Cedro, 1998.

17. L. Song, S. M. AbouRizk, "Measuring and Modelling Labour Productivity Using Historical Data", Journal of Construction Engineering and Management 134 (10): 786-794, 2008.

18. Raport podsumowujący badanie Ministerstwa Rodziny, Pracy i Polityki Społecznej w Polsce "Barometr zawodów 2018”, Wojewódzki Urząd Pracy w Krakowie, Kraków, 2017.

\section{LIST OF FIGURES AND TABLES:}

Fig. 1. Labour productivity unit rates for reinforcement works according to different guides and survey ran on investigated construction sites.

Rys. 1. Normy pracochłonności robót zbrojarskich wg rożnych źródeł i badań przeprowadzonych na budowach.

Fig. 2. The examples of poor experience of ironworkers: incorrectly tied reinforcement of a wall pillar (picture on the left) and a wrong position of starter bars (the bent ones) to be tied with reinforcement of a lift shaft (picture on the right).

Rys. 2. Przykłady niskich kwalifikacji zbrojarzy: nieprawidłowo związane i ustabilizowane zbrojenie filarka ściennego (zdjęcie po lewo) oraz nieprawidłowo wystawione startery (odgięte pręty) do połączenia ze zbrojeniem ściany szybu windowego (zdjęcie po prawo).

Fig. 3. Unacceptably low cover of slab reinforcement.

Rys. 3. Niedopuszczalnie mała otulina zbrojenia stropowego.

Fig. 4. An insufficient spacing of reinforcement bars - an excerpt from construction design.

Rys. 4. Zbyt mały rozstaw prętów zbrojeniowych - fragment dokumentacji projektowej.

Fig. 5. The collected data (on the left) and Random Tree classifier for labour estimation problem (on the right)

Rys. 5. Zgromadzone dane (po lewo) i drzewo losowe problemu szacowania pracochłonności (po prawo).

Fig. 6. Random Forest estimation accuracy measures.

Rys. 6. Miary dokładności przy estymacji lasem losowym.

Tab. 1. Predictors and their values.

Tab. 1. Predyktory i ich wartości.

Tab. 2. Target attribute and its values.

Tab. 2. Atrybut objaśniany i jego wartości. 


\section{MODELOWANIE NORM PRACOCHLONNOŚCI ROBÓT ZBROJARSKICH}

Keywords: roboty zbrojarskie, technologiczność, szacowanie pracochłonności robót, drzewa decyzyjne, agregowane klasyfikatory

\section{SUMMARY:}

Planowanie rzeczowe i kosztowe każdego przedsięwzięcia budowlanego wymaga analizy nakładów pracy. Od pewnego czasu obserwuje się w polskim budownictwie stopniowy spadek dostępności wysoko kwalifikowanej kadry pracowniczej. Z drugiej strony projekty konstrukcyjne obiektów żelbetowych są coraz bardziej złożone i jednocześnie „odchudzane”. Sprawia to, że prawidłowa ocena pracochłonności robót staje się coraz bardziej istotna. Problemy zaobserwowane na różnych krajowych budowach w przeciągu ostatniego roku stały się inspiracją do przeprowadzenia wstępnych badań w temacie pracochłonności prac zbrojarskich. Praca stanowi kontynuację wcześniejszych badań nad modelowaniem pracochłonności robót wykonywanych $\mathrm{w}$ technologii MBB i zaprezentowano w niej możliwość modelowania norm wykonania zbrojenia przy użyciu drzew decyzyjnych (pojedynczych i agregowanych).

Najbardziej wiarygodnym źródłem wiedzy o normach pracochłonności są doświadczenie planującego i baza wiedzy zbudowana na podstawie wcześniejszych realizacji. Jeżeli nie ma możliwości skorzystania z nich, szacowanie pracochłonności wykonania robót można przeprowadzić z wykorzystaniem tablic, wytycznych i katalogów. W Polsce dostępne są Katalogi Nakładów Rzeczowych, w Stanach Zjednoczonych - Tablice „Construction Estimating Reference Data” i podręcznik „DeWalt Construction Estimating Handbook”, krajach niemiecko-języcznych wykorzystuje się aktualizowane co kilka lat poradniki Plümecke, tablice ARH, podręczniki Meiera, Dressa i Kurza, Hoffmanna i Kremera, czy Levsena. Normy zawarte w w/w/ źródłach dotyczą montażu zbrojenia nieprefabrykowanego, uwzględniają transport, ułożenie i wiązanie w konstrukcji, niezbędne cięcie i gięcie prętów. Niestety wartości norm są mocno zróżnicowane co widać na Rys. 1. Oczywiście planując roboty wartości te należy każdorazowo dostosowywać do warunków realizacji - pytanie brzmi: w jakim zakresie? i co decyduje o pracochłonności robót zbrojarskich?

Przeprowadzono wstępne badania na budowach, na których wykonywane były roboty zbrojarskie. Na 6 z 11 budów, inspektorzy nadzoru i kierownicy robót stwierdzili niedoszacowanie pracochłonności i czasu trwania prac zbrojarskich. Jako dwie główne przyczyny zakłóceń wskazano brak kwalifikacji pracowników oraz nieprzywiązywanie przez projektantów wagi do technologiczności projektowanych rozwiązań. Niskie kwalifikacje pracowników skutkowały m.in.: problemami w czytaniu dokumentacji (3/11 budów), myleniem średnic prętów, ich rozstawu, kierunku ułożenia w zbrojeniu dwukierunkowym, nieumiejętną stabilizacją i wiązaniem zbrojenia w konstrukcji (Rys.2, 4/11 budów), czy też problemami z zapewnieniem właściwej otuliny zbrojenia (Rys.3). W kontekście niskiej technologiczności elementów konstrukcyjnych i samego zbrojenia wskazano jako przyczyny opóźnień: zbyt skomplikowane kształty zbrojenia i samych elementów betonowych (6/11 budów), zbyt duże zróżnicowanie średnic w jednym elemencie konstrukcyjnym lub przekroju, zbyt małe tolerancje wykonania, nie uwzględniające możliwości wibrowania i blokowania się mieszanki (6/11 budów), nie przywiązywanie uwagi do ilości gięć i odpadu (5/11 budów), zbyt dużo rozstawów w jednym elemencie (4/11 budów), rozstawy niestandardowe prętów (3/11 budów), nie zwracanie przez projektantów uwagi na wykonawczy aspekt projektowanych detali i efekt jaki mogą mieć dla całej konstrukcji (4/11 budów).

Wskazywany przez respondentów aspekt technologiczności został uwzględniony w proponowanym modelu predykcji norm pracochłonności robót zbrojarskich. Proponowany model to model klasyfikacyjny, w którym narzędziem predykcji są agregowane drzewa decyzyjne. Korzyści płynące z takiego podejścia wyjaśniono we wcześniejszych 
pracach, m.in. w [7,10]. W budowanym modelu występują dwa rodzaje atrybutów - predyktory (zmienne objaśniające, dane wejściowe) oraz atrybut objaśniany. Predyktorami w omawianym problemie są okoliczności wykonywania robot zbrojarskich: typ konstrukcji, doświadczenie zawodowe ekipy, technologiczność elementu konstrukcyjnego i zbrojenia, konieczność dodatkowego docinania zbrojenia, konieczność gięcia zbrojenia, warunki układania zbrojenia. Wartości, jakie mogą przyjmować predyktory zestawiono w Tabeli 1. Atrybutem objaśnianym jest z kolei norma pracochłonności, wyrażona w [rg/t] i określona w czterech przedziałach wartości, podanych w Tabeli 2.

Tabela 1. Predyktory i ich wartości.

\begin{tabular}{|c|c|}
\hline Predyktor & Wartości, jakie może przyjmować predyktor \\
\hline $\begin{array}{l}\text { Typ zbrojonego } \\
\text { element }\end{array}$ & strop (s), ściana (w) \\
\hline $\begin{array}{l}\text { Doświadczenie } \\
\text { zawodowe }\end{array}$ & małe (1, mniej niż 3 lata), średnie (a, 3-12 lat), duże (h, powyżej 12 lat) \\
\hline Technologiczność & $\begin{array}{l}\text { Wartość punktowa od } 0 \text { do } 4 \text { punktów: Sposób wyznaczania: } 1 \text { pkt. - jeżeli } \\
\text { opracowano model 3D zbrojenia lub elementu, } 1 \text { pkt. - jeżeli w elemencie są nie } \\
\text { więcej niż } 2 \text { średnice prętów, } 1 \text { pkt. - jeżeli w przekroju są nie więcej niż } 2 \text { rozstawy } \\
\text { prętów, } 1 \text { pkt. - jeżeli element konstrukcyjny ma standardowy kształt i wymiary }\end{array}$ \\
\hline $\begin{array}{c}\text { Konieczność } \\
\text { dodatkowego gięcia }\end{array}$ & $\begin{array}{l}0 \text { - gdy nie jest wymagane, } 1 \text { - jeżeli koniczne jest mniej niż } 40 \text { gięć / } 40 \text { mb } \\
\text { zbrojenia, } 2 \text { - jeżeli wymagane jest więcej niż } 40 \text { gięć / } 40 \mathrm{mb} \text { zbrojenia }\end{array}$ \\
\hline $\begin{array}{c}\text { Konieczność } \\
\text { dodatkowego cięcia }\end{array}$ & $\begin{array}{c}0 \text { - gdy nie jest wymagane, } 1 \text { - jeżeli koniczne jest mniej niż } 10 \text { cięć / } 40 \mathrm{mb} \\
\text { zbrojenia, } 2 \text { - jeżeli wymagane jest więcej niż } 10 \text { gięć / } 40 \mathrm{mb} \text { zbrojenia }\end{array}$ \\
\hline $\begin{array}{l}\text { Warunki montażu } \\
\text { zbrojenia }\end{array}$ & 0 - obojętne, normalne, 1 - utrudnione, wymagające specjalnych zachowań \\
\hline
\end{tabular}

Tabela 2. Atrybut objaśniany i jego wartości.

\begin{tabular}{|c|c|}
\hline Atrybut objaśniany & Wartości, jakie może przyjmować atrybut \\
\hline Pracochłonność robót & $<30 \mathrm{r}-\mathrm{g} / \mathrm{t}, 30-40 \mathrm{r}-\mathrm{g} / \mathrm{t}, 40-50 \mathrm{r}-\mathrm{g} / \mathrm{t},>50 \mathrm{r}-\mathrm{g} / \mathrm{t}$ \\
\hline
\end{tabular}

Celem klasyfikacji jest znalezienie zależności pomiędzy predyktorami i atrybutem objaśnianym na podstawie danych historycznych. Do zbudowania modelu dla prac zbrojarskich na elementach poziomych wykorzystano 29 obserwacji zarejestrowanych na budowach. Obserwacje te prezentuje Rys. 5. Budując model, w pierwszej kolejności analizowano pojedyncze drzewa decyzyjne, spośród których najlepszy stopień dopasowania uzyskano dla Drzewa Losowego (65,5\%), por. Rys. 5. Następnie dokonano agregacji modelu. Dla algorytmu AdaBoost.M1 dokładność predykcji wzrosła najwięcej, do 73\%, zaś średni błąd spadł do 0,17. Najlepsze rezultaty (por. Rys. 6) uzyskano dla algorytmu Lasu Losowego (79\%). Symulacje prowadzono w środowisku Weka 3.8., zaś zbiór uczący uzyskiwano przy pomocy wielokrotnej kroswalidacji. Oczywiście chciałoby się, by jakość dopasowania była wyższa, zaś klasy - opisane były węższymi przedziałami wartości, co byłoby bardziej przydatne w estymacji czasu trwania robót. Koniczne jest także zbudowanie modelu dla elementów pionowych (ściennych). Powyższe kwestie wymagają uzupełnienia danych i będą kolejnym etapem badań. Warto także zwrócić uwagę na poruszany przez respondentów aspekt technologiczności, która jest w kraju pojęciem niedookreślonym i niedocenianym przez projektantów, a szkoda, bo współczesne techniki projektowe, łącznie z technologią BIM, powinny poprawić technologiczność realizowanych rozwiązań projektowych. 
